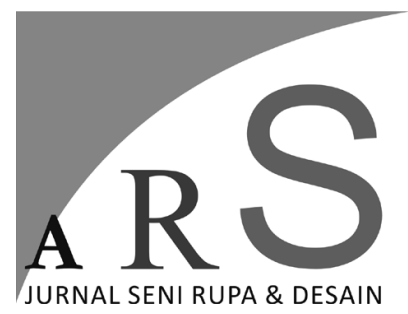

Volume 22 Nomor 1 - April 2019

\section{PATUNG LORO BLONYO PAES YOGYAKARTA SUBJEKTIFITAS DALAM KONSEP KREATIF GUNJIAR}

\author{
Supono \\ Program Magister Pascasarjana ISI Yogyakarta \\ E-mail: pono_gimbal@yahoo.co.id, pono.gimbal00@gmail.com
}

\begin{abstract}
ABSTRAK
Perwujudan bentuk patung loro blonyo paes Yogyakarta masih memegang peranan penting di masyarakat Yogyakarta, karena patung loro blonyo paes Yogyakarta merupakan simbol kerukunan dalam berumah tangga bagi pasangan suami istri, yang mempunyai arti tentang ketentraman hidup dan sebagai simbol Dewi kesuburan. Patung loro blonyo paes Yogyakarta karya Gunjiar yang meliputi: struktur, bentuk, pakaian dan aksesoris lainnya yang dikenakan sebagai bahan acuan dalam menganalisis pemikiran yang melandasi patung loro blonyo paes Yogyakarta. Menginterprestasikan berbagai makna yang terdapat dalam bentuk objek patung loro blonyo paes Yogyakarta sampai sejauh mana makna yang dapat terimplementasikan di dalam kehidupan masyarakat dan melestarikan salah satu bentuk seni patung loro blonyo paes Yogyakarta di masyarakat dan sebagai bentuk interpretasi personal dalam melakukan laku ibadah. Metode penelitian yang digunakan untuk mengkaji masalah-masalah yang berkaitan dengan perwujudan bentuk patung loro blonyo paes Yogyakarta karya Gunjiar adalah metode penelitian kualitatif. Metode studi pustaka, wawancara, dan observasi secara langsung serta menggunakan metode analisis data kualitatif. Penelitian patung loro blonyo paes Yogyakarta melihat lebih mendalam subjektivitas dalam konsep kreatif karya Gunjiar. Menggali lebih jauh sejarah kehidupan Gunjiar dan mengetahui lebih dalam mengenai karya patung loro blonyo paes Yogyakarta dalam konsep berkarya, dan sebagai patung tradisi yang masih menjaga pakem.
\end{abstract}

Kata kunci: Gunjiar, patung loro blonyo paes, Yogyakarta

\begin{abstract}
The embodiment of the form of the statue of loro blonyo in Yogyakarta still plays an important role in the people of Yogyakarta, because the statue of loro blonyo paes Yogyakarta is a symbol of harmony in marriage for a married couple, which has a meaning about peace of life and as a symbol of Goddess of fertility. The statue of loro blonyo paes Yogyakarta by Gunjiar which includes: structures, shapes, clothing and other accessories worn as a reference in analyzing the thoughts underlying the statue of loro blonyo in Yogyakarta. Interpreting the various meanings contained in the object of the statue of loro blonyo in Yogyakarta to the extent of the meaning that can be implemented in the life of the people and preserving one form of loro blonyo paes Yogyakarta in the community and as a form of personal interpretation in performing worship practices. The research method
\end{abstract}


used to examine the problems related to the realization of the form of the statue of loro blonyo paes in Yogyakarta by Gunjiar is a qualitative research method. Library study methods, interviews, and direct observation and using qualitative data analysis methods. The research of the statue of loro blonyo in Yogyakarta sees more depth in subjectivity in the creative concept of Gunjiar's work. Exploring further the history of Gunjiar's life and knowing more about the work of the statue of loro blonyo in Yogyakarta in the concept of work, and as a statue of tradition that still maintains the standard.

Keywords: Gunjiar, the statue of loro blonyo paes, Yogyakarta

\section{Pendahuluan}

Dalam kehidupan masyarakat Jawa berbagai macam ragam seni dan budaya hingga kini masih bertahan dan dijalankan, salah satu bentuk upaya dalam pemaknaan ini dapat ditinjau dari berbagai aspek budaya, salah satu yang tercermin adalah kegiatan ritual upacara, dalam hal ini menjadi bagian penting sebagai wujud representasi masyarakat yang tidak dapat dipisahkan dalam menjalankan laku hidup. Masyarakat Jawa khususnya di Yogyakarta memiliki kaitan erat dalam persinggungan di atas, sebagai Daerah Istimewa yang masih berpegang teguh pada nilainilai warisan budaya, kegiatan ritual upacara dengan konsisten menjadi bagian agenda Keraton Yogyakarta.

Peranan Keraton Yogyakarta menjadi bagian yang tidak terlepas dalam menjaga tradisi dan budaya terutama dalam menjaga warisan leluhur. Warisan berbagai bentuk seni dan budaya yang sampai saat ini masih dapat dilihat yaitu tradisi di lingkup Keraton Yogyakarta, yang hingga kini masih dilakukan yaitu; nguras gentong di kompleks makam Raja-raja yang terletak di Imogiri, mubeng benteng setiap malam satu Suro, Grebeg Maulud Nabi atau sekaten. Keraton Yogyakarta memiliki berbagai benda peninggalan sejarah yang tersimpan di dalam lingkungan Keraton maupun di museum Sonobudoyo, seperti kereta kencana, tombak, keris, buku, patung, dan lain-lain.

Salah satu peninggalan yang berupa patung adalah patung loro blonyo paes Yogyakarta. Perwujudan berupa bentuk sepasang patung pengantin duduk berdampingan mengenakan pakaian adat Jawa Yogyakarta. Patung tersebut merupakan salah satu patung yang disakralkan. Pada awalnya patung loro blonyo paes khas Yogyakarta hanya dapat dimiliki oleh kaum bangsawan di kerajaan Mataram Islam Yogyakarta, dan dipercaya sebagai simbol status sosial di masyarakat. Dalam perkembangannya patung loro blonyo paes Yogyakarta mengalami pergeseran status sosial di masyarakat, kini masyarakat umum sudah dapat memiliki patung loro blonyo paes Yogyakarta, karena sudah menjadi barang komoditi yang dipasarkan secara bebas sampai mancanegara.

Tersebutlah nama Gunjiar, seorang perajin paes yang hidup di Yogyakarta. Gunjiar tinggal bersama isteri dan keempat anaknya, tiga perempuan dan satu laki-laki. Gunjiar sudah 60 tahun tinggal di Dusun Krebet, sebuah desa dengan geografis tanah perbukitan berkapur yang kurang produktif. Sebagian besar masyarakat Krebet awalnya mengandalkan mata pencarian sebagai petani. Sistem pertanian dengan pengairan tadah hujan artinya mereka menanam pada musim penghujan, dengan sangat terbatas pada jenis tanaman palawija. Dusun Krebet merupakan bagian wilayah yang terletak di Desa Sendangsari, Kecamatan Pajangan, Kabupaten Bantul, Daerah Istimewa Yogyakarta.

Asal usul peletakan patung loro blonyo paes menurut Gunjiar berada di dalam rumah adat Jawa yang terletak di senthong/paseman (kamar). Patung loro blonyo paes memiliki kesamaan dengan kembar mayang yang digunakan pada acara 
pernikahan dalam tradisi Jawa, sebagai simbol kerukunan dalam berumah tangga. Patung loro blonyo paes ada beragam jenis menurut gayanya, yaitu; loro blonyo paes pengantin ageng Jogja, loro blonyo pengantin ageng Solo, loro blonyo pengantin ageng Mangkunegaran, dan ada juga perwujudan patung loro blonyo paes yang tidak mengenakan pakaian lengkap adat Jawa.

Gunjiar membuat patung loro blonyo paes pertama kali atas perintah $\mathrm{Ki}$ Romo Wiknyowardoyo seorang bekel dari Keraton Yogyakarta, ia diajak ke Keraton untuk melihat dan mengamati secara langsung bentuk perwujudan patung loro blonyo paes Yogyakarta sebagai acuan dalam proses perwujudan bentuk patung. Dengan berdasarkan acuan tersebut, Gunjiar mulai mengerjakan patung loro blonyo paes di daerah Tungkak, Yogyakarta. Pembuatan patung loro blonyo paes Yogyakarta selesai dikerjakan dan, untuk museum HB IX. Dalam proses pembuatan patung Gunjiar meminta bimbingan pada Ki Wiknyowardoyo hal yang terkait atribut, aksesoris dan pakaian yang dikenakan sesuai kepakeman patung yang ada di Keraton Yogyakarta.

Bentuk bagian atas kepala laki-laki memakai kuluk dan perempuan memakai cunduk mentul, dahi dihias, dan bagian rambut belakang disanggul dan ditutupi dengan rangkaian bunga melati. Sanggul kanan bagian bawah dipasang rangkaian bunga melati. Bentuk bagian bawah selain sebagai landasan juga untuk membedakan perwujudan bentuk, patung laki-laki dengan posisi sikap duduk bersila, dan patung perempuan dengan posisi sikap duduk timpuh. Sepasang patung loro blonyo paes tersebut duduk berdampingan, laki-laki disebelah kanan dan perempuan disebelah kiri yang memiliki simbol sebagai sepasang pengantin paes Yogyakarta. Bentuk patung loro blonyo paes Yogyakarta karya Gunjiar sampai saat ini, di dalam proses pembuatannya masih menggunakan pakem dan tata cara tradisional. Dari awal proses hingga akhir proses perwujudan bentuk, pakaian, atribut, dan aksesoris, yang dikenakan mengacu pada paes Yogyakarta. Meskipun perkembangan jaman sudah maju, Gunjiar masih tetap menjaga dan melestarikan patung loro blonyo paes yang sesuai pakem seni tradisi.

\section{Metode Penelitian}

Metode penelitian ini menggunakan langkah-langkah secara sistematis yang digunakan untuk penelitian. Pada tahapan ini penelitian yang digunakan untuk mengkaji masalah-masalah yang berkaitan dengan perwujudan bentuk patung loro blonyo paes Yogyakarta karya Gunjiar adalah metode penelitian kualitatif. "Menurut Bogdan dan Taylor, penelitian kualitatif merupakan prosedur yang memproduksi data deskriptif berupa data-data tertulis atau lisan dari orang-orang dan perilaku yang diamati." (Moeloeng, 2009:4)

Penelitian patung Loro blonyo paes Yogyakarta melihat lebih mendalam subjektivitas dalam konsep kreatif karya Gunjiar.Menggali lebih jauh sejarah kehidupan Gunjiar dan mengetahui lebih dalam mengenai karya patung Loro blonyo paes Yogyakarta dalam konsep berkarya.

Pendekatan yang dilakukan melihat langsung kehidupan sehari-hari dan wawancara yang terkait patung Loro blonyo paes Yogyakarta sehingga dapat menjadi sumber data untuk menelaah lebih jauh mengenai perwujudan bentuk patung Loro blonyo paes Yogyakarta. Data yang diperoleh dari buku tersebut, digunakan peneliti sebagai acuaan untuk menjabarkan pemakna patung Loro blonyo paes Yogyakarta baik secara perwujudan bentuk maupun makna yang saat ini sudah banyak mulai dilupakan perwujudan bentuk dan makna patung Loro blonyo paes Yogyakarta.

Ada beberapa variabel yang digunakan dalam penelitian. Variabel tersebut meliputi beberapa hal atau berhubungan langsung dengan suatu objek penelitian. Berdasarkan variabelvariabel fisik perwujudan patung loro blonyo paes Yogyakarta, peneliti akan melihat karya Gunjiar. dari bentuk perwujudan sepasang patung pengantin mengenakan pakaian adat Jawa paes Yogyakarta lengkap dengan segala atribut dan aksesorisnya. Sepasang patung pengantin dengan sikap duduk saling berdampingan, posisi sikap duduk laki-laki bersila dan perempuan posisi sikap duduk timpuh. Konsep kreatif Gunjiar di dalam Perwujudan bentuk patung loro blonyo paes Yogyakarta adanya nilai kesakralan dalam proses pembuatan awal hingga akhir proses variabel ini penting untuk melihat pentingnya patung loro blonyo paes bagi masyarakat Yogyakarta. 
Pengambilan sampel penelitian ini adalah patung loro blonyo paes Yogyakarta karya Gunjiar. Patung loro blonyo paes Yogyakarta ini akan diteliti dan digali dengan mengambil sampel berupa perwujudan sepasang patung pengantin adat Jawa paes Yogyakarta beserta atribut dan asesoris yang dikenakan yang melekat pada sepasang patung penting yang berdampingan tersebut. Dari bentuk atas kepala, bagian badan tengah, bagian badan bawah dan segala kelengkapan atribut dan asesoris yang terdapat pada patung loro blonyo paes Yogyakarta tersebut. Makna patung Loro Blonyo bagi Gunjiar dan masyarakat Yogyakarta. Pengambilan sampel perwujudan patung loro blonyo paes Yogyakarta ini berdasarkan pada perwujudan bentuk patung tersebut, sehingga dapat diperoleh pemahaman serta maksud konsep kreatif Gunjiar dalam patung loro blonyo paes Yogyakarta.

Adapun wawancara telah dilakukan oleh peneliti dengan Gunjiar dan beberapa abdi dalem Keraton Yogyakarta. Hal ini dikarenakan patung loro blonyo paes di Yogyakarta erat hubungannya dengan masyarakat serta Keraton Yogyakarta. Sehingga data yang diperoleh lebih akurat dari lingkup masyarakat dan keluarga Keraton Yogyakarta. Metode observasi digunakan agar peneliti secara langsung dapat melihat dan mengamati sendiri serta mencatat informasi-informasi dari informan, sehingga memungkinkan bagi peneliti untuk mencatat segala suatu keadaan situasi yang terkait dengan pengetahuan yang diperoleh secara langsung dari data. Observasi yang dilakukan dengan melihat keunikan dan kreativitas perwujudan patung loro blonyo paes Yogyakarta karya Gunjiar secara langsung, akan diperoleh suatu gambaran yang nyata dari sebuah obyek penelitian.

Proses analisis data dalam penelitian ini yang meliputi beberapa tahapan. Tahap pertama, dengan melakukan indentifikasi data, mengumpulkan data verbal dan data visual, baik yang diperoleh dari studi pustaka, observasi, maupun wawancara. Tahap kedua, mengklasifikasikan data sesuai yang telah teridentifikasi sesuai dengan jenis dan sifat data. Tahap ketiga, yaitu menyeleksi data dengan menyisihkan data yang tidak relevan dan kurang berkontribusi terhadap kebutuhan pokok dalam bahasan. Pada tahap keempat yaitu dengan melakukan analisis data yang sesuai dengan teori-teori yang telah ditetapkan sebelumnya, patung loro blonyo paes Yogyakarta karya Gunjiar baik menggunakan analisis tekstual maupun kontekstual dan selanjutnya akan disajikan dalam suatu bentuk karya tulis ilmiah.

\section{Hasil Pembahasan}

Berdasarkan penelitian yang telah dilakukan dengan menggunakan metode observasi secara langsung, melakukan wawancara serta studi pustaka, maka memperoleh beberapa data dan fakta di lapangan. Dari situ diketemukan kebentukan patung tradisional yang masih memegang pakem, namun dalam atribut dan asesoris mengacu pada rias pengantin gaya paes Yogyakarta. Subjektivitas dalam konsep kreatif Gunjiar memiliki pandangan bawah konsep, ide, kreativitas, orientasi nilai, bentuk dan sebagainya merupakan sebuah keteguhan keyakinan terhadap Tuhan.

Dibandingkan dengan arca-arca sebelumnya, patung loro blonyo paes yang merupakan salah satu jenis seni patung tradisional-klasik di Jawa, tampilannya masih menunjukan ciri-ciri pasangan laki-laki, dan perempuan yang berkaitan pula dengan konsepsikonsepsi penyatuan dari pasangan yang berbeda. Memang patung ini tidak ditemukan di suatu candi sebagaimana patung atau arca masa prasejarah, ataupun masa Hindu-Budha, namun patung loro blonyopriyayi Jawa yang disebut joglo. (Soeratman, 1989:29)

Perwujudan patung loro blonyo paes Yogyakarta secara filosofis sepasang pengantin duduk berdampingan tidak bisa dipisahkan yang berada di rumah adat Jawa seperti limasan dan joglo. Loro blonyo sendiri dapat didefinisikan sebagai sepasang patung yang terbuat dari bahan kayu, yang terdiri dari patung seorang perempuan (rara) yang didampingi seorang lakilaki dengan mengenakan busana perkawinan adat Jawa, gaya basahan dalam posisi duduk, yang penempatannya pada rumah joglo, yaitu tepatnya di senthong tengah, atau di sebelah kanan, dan kiri krobongan yang berfungsi simbolis bagi pemiliknya. (Soeratman, 1989:208; Santoso, 2000:88) 
Dalam konteks ini jelas bahwa seni patung bukan sekedar kesatuan bentuk yang tersusun oleh garis, bidang, warna, teksture dan valume yang besifat keindahan visual semata. Kepercayaan sepasang patung pengantin sebagai lambang dewi kesuburan dan kerukunan berumah tangga pasangan suami istri.Perwujudan patung sebagai perwujudan yang memiliki adanya kekuatan Roh, membawa pesan bagi masyarakat untuk menjaga dan selalu setia pada pasangannya. Dalam konsep perwujudan tersebut merupakan suatu filosofi makna patung loro blonyo paes Yogyakarta.

Sepasang patung loro blonyo paes Yogyakarta karya Gunjiar merupakan pencerminan bentuk tampilan realis, yang menyerupai struktur anatomi kebentukan dan bentuk manusia layaknya. Unsur-unsur yang terdapat pada patung loro blonyo paes Yogyakarta yang secara perwujudannya baik bentuk, ekspresi wajah, jenis aksesoris yang dikenakan, kesan pada bahan, warna, posisi duduk dan sikap yang terdapat pada patung, secara keseluruhan menggambarkan pesan simbolik yang mempresentasikan kewibawaan dan keagungan pada patung. Rambut berwarna hitam lurus halus sebagian digelung dan mengenakan asesoris konde warna keemasan yang mengunakan bahan warna dari tembaga. Pada bagian ujung telinga terdapat hiasan berupa sumping dengan rambut cambang memanjang tampak rapi.

Bentuk sumping yang mengerucut merupakan garis yang saling bertemu pada ujungnya yang ada perpedaannya bawah lebih lebar dan bagian atas runcing maka akan membentuk segitiga dan adanya garis yang saling bertemu menjadi bentuk bidang lingkaran yang menyatu dengan bidang segitiga. Pada bagian telinga adanya garis yang saling bertemu yang mengantung pada ujungnya membentuk benang dan adanya garis melingkar dan garis tegak lurus bentuknya lingkaran selinder bawah lebih besar dan atas lebih kecil.

Bagian tengah patung loro blonyo paes Yogyakarta perempuan mengenakan beberapa busana dan asesoris kain dodot difungsikan sebagai kemben. Pada bagian dada adanya garis lingkaran pipih yang melingkari tubuh bagian dalam, bidang lingkaran ini terdiri dari titik dan garis yang berulang-ulang dan menghasilkan bentuk ornamen. Setagen bidang garis lingkaran pipih yang melingkar pada perut adanya bidang segi empat tidak sama. Sisi-sisi pada bagian tengah terdapat garis lingkaran. Pada bagian pengantin perempuan mengenakan kain cinde dan kain jarik sidho mukthi atau kebaya. Pada bagian perut sampai dada mengenakan kemben bagian dalam dan bagian luar mengenakan setagen, berfungsi untuk mengencangkan serta memperindah setagen yang melingkar berwarna emas adanya kombinasi warna merah dan coklat dengan hiasan motif ornamen. Pada bagian kemben yang dikenakan berwarna bermacam-macam seperti warna coklat, merah, biru, kuning, hijau dan putih.

Garis lengkung dan garis cembung yang dilakukan berulang-ulang menghasilkan adanya kebentukan bidang lingkaran tersebut menjadi sepasang gelang yang dipakai dikedua pergelangan tangan kanan dan kiri. Pada bagian kedua pergelangan tangan adanya bidang garis yang melingkar saling bertemu membentuk bidang lingkaran dengan ukuran yang sama saling bertemu dan menyatu. Sehingga bentuk tersebut menjadi gelang biasa atau gelang polos tidak ada bentuk ornament seperti yang dipakai dipergelangan tangan. Pada bagian gelang yang dipakai dipergelangan tangan adanya penyederhanaan kebentukan model. Pada bagian bawah garis lurus dan lengkung yang saling bertemu pada ujungnya membentuk bidang dasar dari patung sekaligus sebagai pondasi patung dengan posisi duduk timpuh. Garis-garis yang terdiri dari lengkung, cembung, lurus dan tak beraturan menjadi bagian yang tersusun dari dasar perwujudan patung loro blonyo paes Yogyakarta.

Patung loro blonyo paes mempunyai empat bentuk fisik yaitu: kepala pada bagian atas, badan, tangan, dan pada bagian bawah sebagai landasan, kepala yang menyatu dengan kelengkapan aksesoris pengantin Paes Yogyakarta baik laki-laki dan perempuannya. Pada patung laki-laki kepala menyatu dengan penutup kepala yang disebut khuluk kanigara yang memiliki garis melingkar dibagian bawah dan atas. Pada patung perempuan ada kesamaan kepala menyatu dengan sanggul atau gelungan berserta cunduk menthul pada bagian atas, sanggul atau gelungan terdapat adanya roncean bunga melati, roncean bunga melati yang memanjang kebawah dipasang pada sanggul sebelah kanan. Sepasang 
patung pengantin merupakan bentuk patung yang menjadi dasar dari patung loro blonyo paes Yogyakarta. Perwujudan bentuk patung ini merupakan perwujudan dari Dewi Sri dan Sadono yang merupakan lambang kerukunan dalam berumah tangga bagi pasang suami istri serta kesuburan dan kemakmuran.

Dengan demikian perwujudan patung loro blonyo paes Yogyakarta perempuan dengan sikap posisi duduk timpuh kedua telapak kaki kanan dan kiri tidak terlihat membedakan sikap posisi duduk laki-laki. Pakaian yang dikenakan beserta aksesorisnya mencerminkan perempuan Jawa pada konteksnya sebagai ratu. Sepasang patung Loro blonyo paes Yogyakarta karya Gunjiar pada bagian tubuhnya berwarna putih kecoklatan, pada bagian aksesori mengunakan warna emas dan pada atribut menggunakan beberapa warna yaitu warna merah, kuning, hijau, biru, coklat tua, coklat muda, hitam dan putih.

Perwujudan patung loro blonyo paes Yogyakarta di atas bentuk-bentuk tersebut terdiri titik dan garis merupakan unsur visual dalam kebentukan seni untuk mendapatkan hasil karya dari senimannya. Dengan mengolah unsurunsur tersebut dapat dikatakan suatu proses bentuk karya seni patung seperti perwujudan sepasang patung loro blonyo paes Yogyakarta. Di dalam menciptakan karya seni patung ukuran atau proporsi merupakan bagian utama untuk mendapat kebentukan gaya sehingga keindahan dan keseimbangan perwujudan dapat tercapai. Dilihat perwujudan patung loro blonyo paes Yogyakarta karya Gunjiar memiliki bentuk dekoratif dan realistis.

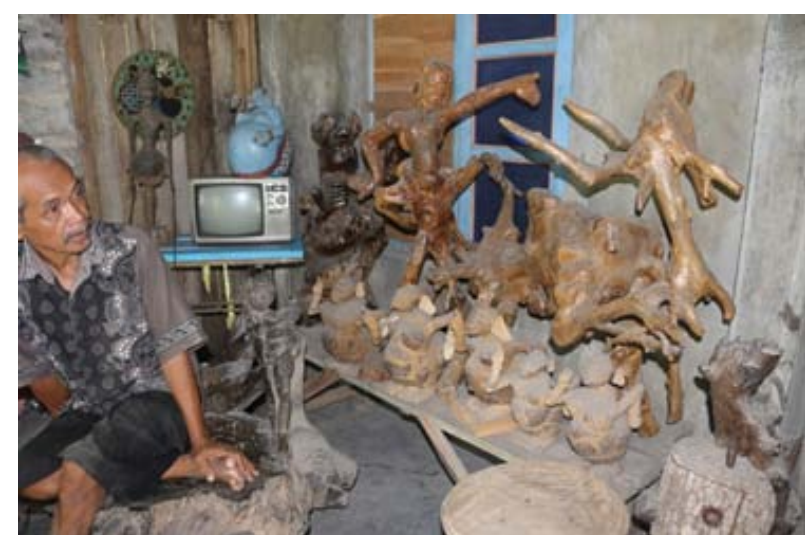

Gambar 1. Gunjiar dan karya lainnya Foto diambil oleh Supono pada 17 Desember 2018

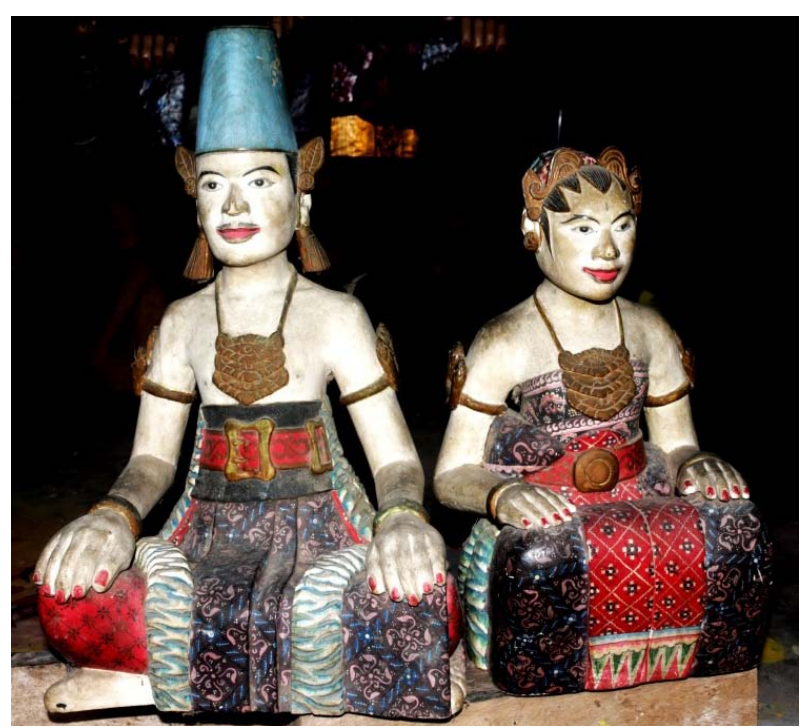

Gambar 2. Sepasang patung loro blonyo paes Yogyakarta

Karya Gunjiar tampak depan

Foto diambil oleh Supono pada 07 januari 2017)

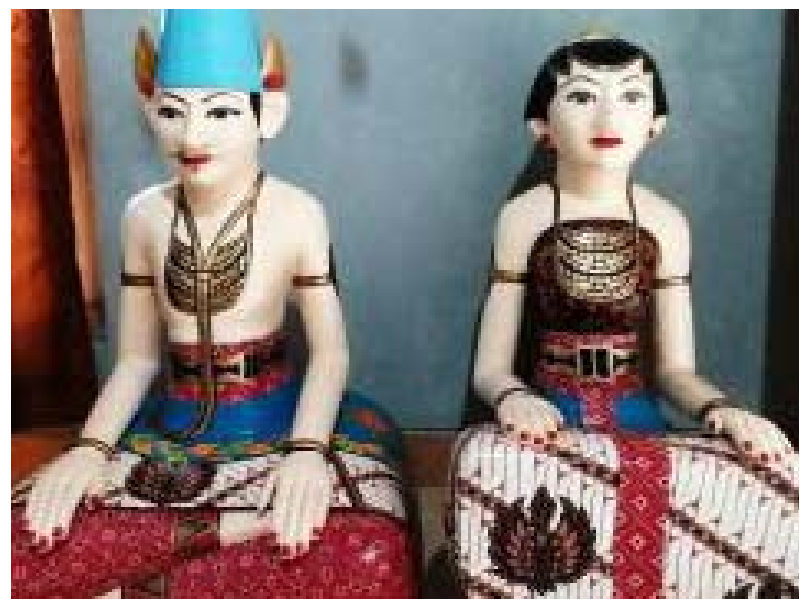

Gambar 3. Patung loro blonyo paes. Sumber:https://inkuiri.com/site/olx.co.id/ rumah-tangga-surabaya-kota/dekorasi-rumahsurabaya-kota/dwie-nc-patung-loro-blonyo. a09c3e9f2e0bc932fba23a79954e21f951239998.id (diunduh pada: 01/25/2019 17:25: 37 AM)

\section{Kesimpulan}

Gunjiar mempertahankan membuat patung loro blonyo paes Yogyakarata tadisional, sebagai orang Jawa merasa terpanggil dan menjadi tanggung jawab untuk menjaga dan melestarikan warisan budaya. Di dalam berkarya dasar kepercayaan dan keyakinan bahwa segala sesuatu yang ada didunia berserta isinya sudah ada yang mengatur. Kehidupan manusia tidak terlepas dari alam semesta berserta isinya. 
Makna patung loro blonyo paes Yogyakarta Gunjiar memegang teguh idealis dalam berkarya tidak merubah dan masih menjaga nilai-nilai kesakralannya sebagai patung tradisi. Gunjiar memiliki sudut pandang setiap hasil karya apapun mempunyai kekuatan yang diberikan Tuhan, sehingga dalam konsep kreatif berkarya memegang teguh keyakinan sebagai Orang Jawa yang memiliki laku spiritual. Patung loro blonyo paes Yogyakarta karya Gunjiar sendiri merupakan patung tradisi yang disakralkan yang mengacu pada Keraton sepasang pengantin gaya paes Yogyakarta, simbol bagi masyarakat Yogyakarta khususnya dan pada umum Jawa. Hal ini disebabkan pada makna filosofi Patung loro blonyo paes Yogyakarta tidak dapat dikerjakan tanpa ada proses ritual terlebih dahulu, dalam mana hal tersebut masih tercermin pada karya Gunjiar, sebagaimana dibuktikan dalam penelitian ini.

\section{Daftar Pustaka}

Moeloeng, L. J. (2007). Metodologi Penelitian Kualitatif. Bandung: Rosdakarya.

Santoso. RB. (2000). Omah: Membaca Makna Rumah Jawa. Yogyakarta: Bentang Budaya.

Soeratman, D. (1989). Kehidupan Dunia Keraton Surakarta 1830-1939. Yogyakarta: Taman Siswa.

\section{Website}

https://inkuiri.com/site/olx.co.id/rumahtangga-surabaya-kota/dekorasi-rumahsurabaya-kota/dwie-nc-patung-loro blonyo. a09c3e9f2e0bc932fba23a79954e21f9 51239998.id (diunduh pada: 01/25/2019 17:25: 37 AM) 